\title{
COMMONWEALTH OF DOMINICA
}

Area: 751 sq. km

Population: 83,500

Capital: Roseau

Head of State: Aurelius Marie (President)

Minister of Home Affairs: Brian G. K. Alleyne

Emergency Services: 999

Dominica is the largest of the Windward Islands. It became an independent republic in November 1978.

The Dominica Police Force has about 280 personnel and 20 police stations. It is headed by a Chief of Police, who is also the Traffic Commissioner, and generally limited to public order and traffic control duties.

There is a Police Training School at Morne Bruce, northeast of Roseau.

Police Headquarters, King George V Street, Roseau (2222)

Police Training School, Morne Bruce (2050) 